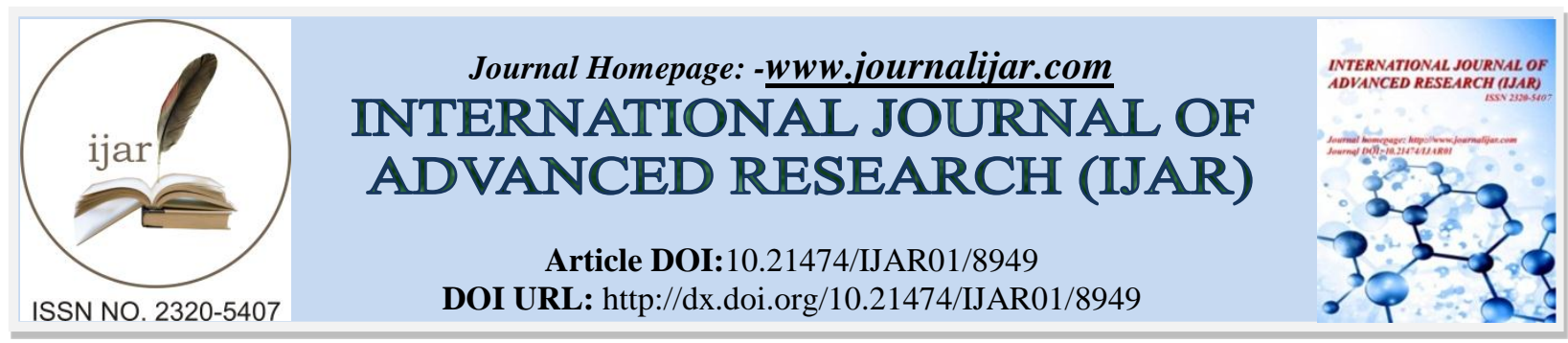

RESEARCH ARTICLE

\title{
FREQUENCY OF HBV, HCV, HIV AND SYPHILIS IN BLOOD DONORS AT BLOOD BANK IN BAHAWAL VICTORIA HOSPITAL, BAHAWALPUR.
}

\author{
Dr.Iftikhar Ahmed, Dr.Yumna khan, Dr.Tehreem Fatima,Dr.Muhammad Afzal Randhawa, Dr.Naila \\ Shabbir and Dr.Aamra Saeed.
}

\section{Manuscript Info}

Manuscript History

Received: 22 February 2019

Final Accepted: 24 March 2019

Published: April 2019

Key words:-

Blood donors, blood bank, HBV, HCV

,Frequency, Syphilis.

\begin{abstract}
Introduction:Blood transfusion is a potentially important source of the transmission of blood-borne infections such as HBV, HCV, HIV and syphilis. Data from screening may serve as an important source of information about frequency of various infectious pathogens in blood donor population and to some extent in the general population. Objective:The objective of the study was to determine the frequency of $\mathrm{HBV}, \mathrm{HCV}$, HIV and syphilis in blood donors at blood bank in Bahawal Victoria Hospital, Bahawalpur, Pakistan. Methods:It is a Cross sectional descriptive study. Study was started in May 2018 and completed in June 2018. The setting of the study was blood bank of Bahawal Victoria Hospital, Bahawalpur. A sample of 100 people was taken. Non probability convenient sampling. The information was collected through a preformed questionnaire. The information regarding results of the screening tests of HBV, HCV, HIV and syphilis of blood donors performed at the time of donation was collected from the previous record. Data was analyzed manually. All results were presented in the form of tables and graphs. Results:The $17 \%$ of the blood donors at blood bank of Bahawal Victoria Hospital, Bahawalpur were found to be infective, among these the frequency of HBV, HCV, HIV and Syphilis was 5\%, 8\%, $0 \%$ and $4 \%$ respectively. Conclusion:Sharing of scissors, shaving from barber and I/V drug using practices/reuse of syringes were surprisingly frequent among people, which had top-listed the risk factors for hepatitis and AIDS. The most frequent infection among blood donors was HCV 8\%, followed by HBV 5\% and Syphilis 4\%. The results seek an urgency to create awareness among people regarding these risk factors.
\end{abstract}

Copy Right, IJAR, 2019,. All rights reserved.

\section{Introduction:-}

Blood transfusion is a life-saving intervention and millions of lives are saved every year globally through this procedure ${ }^{1}$. However, blood transfusions are associated with certain risks, which can lead to adverse consequences. It may cause acute or delayed complications and carries the risk of the transmission of infections ${ }^{2}$. Access to safe blood and blood products still remains a major challenge throughout the world. Unsafe blood transfusion is very

Corresponding Author:-Iftikhar Ahmed. 
costly from economic point of view. The blood transfusion services often struggle against competing demands for increasingly restricted resources and have remained a low priority within health care budgets so far.

Blood is one of the major sources of transmission of hepatitis B, hepatitis C, HIV and Syphilis. In Pakistan more than 1.5 million pints of blood are collected each year ${ }^{3}$. Out of these about $65 \%$ is from replacement donors, $25 \%$ from volunteer donors and about $10 \%$ from professional donors ${ }^{4}$.

Blood component transfusion is a potentially important source for the transmission of blood borne infections. Careful selection and screening of blood donors are crucial strategies to reduce this risk. Data from screening may serve as an important source of information about prevalence of various infectious pathogens in the blood donor population and to some extent in the general population. Globally, transfusion of contaminated blood causes up to 16 million new infections with hepatitis $\mathrm{B}$, and 5 million new infections with hepatitis $\mathrm{C}$ every year ${ }^{5}$.With each blood unit transfused, there is always a $1 \%$ likelihood of transfusion-linked risks including transfusion-transmitted infection ${ }^{6}$. Screening for transfusion-transmitted infections(TTIs) is a critical part of blood transfusion process as it ensures that transfusion is as safe as possible.

Blood-borne transmission remains a key vector of the Hepatitis B and C infections in Pakistan, affecting about 7.4\% of the population ${ }^{7}$. The frequency of HIV and syphilis is low but High Risk Group (HRGs) have shown a higher prevalence rate for syphilis ${ }^{8}$ and HIV/AIDS $^{9}$.

International statistics show the prevalence of $\mathrm{HBV}, \mathrm{HCV}, \mathrm{HIV}$ and syphilis in blood donors to be $2.35 \%, 0.79 \%$, 0.145 and $0.34 \%$ respectively ${ }^{10}$. While the national statistics of prevalence of HBV, HCV, HIV and syphilis in blood donors are $8.34 \%, 3.91 \%, 0 \%$ and $0.89 \%$ respectively ${ }^{11}$. In developing countries lack of resources for universal and effective screening of blood donors is still a major source of transmission of infections in the recipients.

The health care system for blood transfusion in Pakistan is weak and as it does not offer any record management for donors. Proper administrative structure for the blood transfusion exists only in Punjab ${ }^{12}$. Because of the increasing incidence of transfusion-transmitted infections, it is realized that it is the need of the hour to establish an efficient safe blood transfusion programme. So, safe blood transfusion programme is initiated under the Punjab safe blood transfusion Act 1999. Punjab safe blood transfusion authority (PBTA) comprises of Director-General Health, Additional Health Secretory, One member from Provincial Assembly and one member from Armed forces. The aims of the Punjab blood transfusion authority are, first, establishment of blood transfusion and screening centers in all the big hospitals of Punjab. These are not autonomous but regulated bodies and consists of technical experts, law officers, public health officers and trained and qualified hematologists. Second, a awareness campaign should be initiated at province and district level to create awareness among peoples regarding health hazards of unsafe blood transfusion, and the awareness team include Government, Journalists, Showbiz, Social-workers and representatives of civil society.

The possibility of transmission of infections would be minimized if blood is collected from low risk targeted general public. We undertook a review of frequency of serological evidence of hepatitis B, hepatitis C, human immunodeficiency virus (HIV) and Syphilis over a month's period. Data from our institution of 100 donors over a month's span present a unique opportunity to evaluate trends in frequency of these diseases in Bahawalpur.

\section{Literature Review}

Blood transfusion has become an essential part of treatment in any medical or surgical emergencies. Transfusion transmissible infections (TTIs) pose a major health risk and there is a high prevalence of such pathogens and increased demands for blood donations in local communities. The study aims as determining the prevalence of commonly encountered transfusion transmissible infections among the blood donors and transfusion related complications among the recipients in a particular community.

In a survey held in urban centre of Cameroon, a total of 477 donors were recruited by consecutive sampling. Serum samples were tested by various rapid diagnostic tests for presence of HBV, HCV, HIV and Treponema Pallidum. Of the 477 blood donors, 64 were infected by at least one of the four transfusion transmissible infections. Prevalence of HCV, HIV, HBV and Treponema Pallidum were found to be $1.3 \%, 1.8 \%, 3.5 \%$ and $6.81 \%$ respectively ${ }^{13}$. 
In an other study, conducted to evaluate the sero-prevalence of HBV, HCV, HIV, Syphilis and malaria among the blood donors in Bhopal along the duration of 3.5 years. The study included records of 2842 voluntary and 6718 replacement donors. Sero-prevalence of HIV, HBV, HCV, Syphilis and malaria was found to be $0.09 \%, 0.80 \%$, $1.19 \%, 0.73 \%$ and $0.00 \%$ in the voluntary donors and $0.45 \%, 0.59 \%, 0.80 \%, 1.78 \%$ and $0.00 \%$ in replacement donors. Overall transfusion-transmissible infections prevalence in voluntary and replacement donors was $2.81 \%$ and $3.62 \%$ respectively ${ }^{14}$.

Similarly in another retrospective observational study carried out in SS Medical college, Rewa, India, over a period of 5 years, all blood donor samples were screened for HBV, HCV, HIV. Out of 29540 donors, 28117 (95.18\%) were males and $1428(4.82 \%)$ were females. Among all donors, majority $(56.98 \%)$ are in age group of $18-30$ years. The overall sero-prevalence of $\mathrm{HBV}, \mathrm{HCV}$ and HIV was found to be $1.18 \%, 0.33 \%$ and $0.80 \%$ respectively ${ }^{15}$.

A retrospective study was conducted in Federal Medical Centre, South Eastern Nigeria in 2012. In a sample size of 2626 blood donors, of which $2292(87.3 \%)$ were males, $271(10.3 \%)$ females and $63(2.4 \%)$ cases were of undocumented gender. Majority of the donors were within age group 29-39 years. The sero-prevalence of HIV, HBV , HCV and syphilis were $0.3 \%(\mathrm{~N}=8), 0.3 \%(\mathrm{~N}=8), 0.1 \%(\mathrm{~N}=3)$ and $0.06 \%(\mathrm{~N}=2)$ respectively ${ }^{16}$. The study reveals low prevalence of transfusion transmissible infections among blood donors.

In another retrospective study which was conducted at Gondar University Teaching Hospital North East Ethiopia in 2010. The results showed from a total sample size of 6361 blood donors, $10.5 \%$ had serological evidence of infection. The overall seroprevalence of HIV, HBV, HCV and syphilis was 3.8\%, $4.7 \%, 0.7 \%$ and1.3\% respectively ${ }^{17}$. Study showed that a substantial percentage of blood donors harbor HIV, HBV HCV and syphilis.

\section{Discussion:-}

Health care system of developing countries are continuously facing the challenges of inadequate supply of safe blood and an increase in frequency of transfusion associated infections.

In our study, we discussed about variables including history of blood transfusion, ear piercing, tattooing, barber visiting, and history of jaundice, previous surgery and intravenous drug abuse.

The study conducted in Krishnagri India in 2013, according to their data $2.6 \%$ were HBV positive and $3.70 \%$ were HBV negative, among the subjects with history of ear piercing ${ }^{18}$. While a study conducted in Australia in 2011, the prevalence rate of $\mathrm{HCV}$ was $31.5 \%$ among the subjects with history of ear piercing ${ }^{19}$. While according to our study, the prevalence rate of $\mathrm{HCV}$ was $7.69 \%$. So we concluded that the prevalence rate is higher in Australia, then in Bahawalpur and least in India.

Among the subjects with history of jaundice, the prevalence rate of hepatitis B was $3.20 \%$ in India ${ }^{18}$, the prevalence of hepatitis C was $4.01 \%$ in Austrlia ${ }^{19}$, while in our study the prevalence of both hepatitis B and C was $22.2 \%$.

Report from NEW YORK in 2010 showed 59\% HBV positive and 0.77\% HIV positive among intra-venous drug users $^{18}$. A study conducted in USA in 2012 showed that there were $0.26 \% \mathrm{HCV}$ positive and $0.4 \%$ were HBV positive among intravenous drug users ${ }^{22}$. While in our study $9.5 \%$ were HCV positive and $3.04 \%$ were HBV positive among intra-venous drug users.

Among the subjects with history of previous surgery ,5.30\% were HBV positive in KRISHNAGRI INDIA ${ }^{20}$ in 2012 , $4.28 \%$ were $\mathrm{HCV}$ positive in Australia in 2011. While in our study $12 \%$ of donors were having history of previous surgical intervention but all were non-infective.

Report from Krishnagri India in 2012 showed the prevalence of HBV was $10.4 \%$ among barber visitors ${ }^{20}$, while these figures were $6.7 \%$ and $8.6 \%$ in Australia and USA respectively. While in our study $8.5 \%$ were HCV positive and $6.84 \%$ were $\mathrm{HBV}$ positive among barber visitors.

Prevalence rate of Treponema Pallidum was $17.4 \%$ among subjects with history of tattooing and $0.33 \%$ among blood donors in studies conducted in CHICAGO and USA in 2012 respectively ${ }^{5}$. While in our study, it was $1 \%$ among subjects with history of tattooing and $2.8 \%$ among blood donors. 
The first five cases of HIV in U.S were reported in 1981. More than 1000,000 Americans have the virus today .The HIV pandemic is most severe in Sub-Saharan Africa. Over 60\% of all people living with HIV reside within this region.

Adult HIV prevalence exceeds 20\% according to studies conducted in Swaziland, Botswana And Lesotho in 2011. While an additional six countries reported HIV prevalence of at least $10 \%$.

In terms of raw HIV case numbers SOUTH AFRICA has largest population living with HIV(6.3 million), followed by NIGERIA (3.2 million) and INDIA (2.1 million) by the end of 2013.

0n the other end of spectrum, Svalbard is reported as having no case of HIV/AIDS.

While Bhutan has a much larger population but still only an estimated 246 cases through 2011 . Countries such as Afghanistan and Cape Verde are reported to have the lowest prevalence, less than $0.1 \%$. In our study, there is no case of HIV/AIDS i.e. $0 \%$ prevalence rate.

In this way, we concluded through our discussion that HBV. HCV and Syphilis are more common among subjects with history of blood transfusion, history of intravenous drug users, history of previous surgery and history of tattooing.

\section{Objective}

The objective of the study was to determine the frequency of HBV, HCV, HIV and syphilis in blood donors at blood bank in Bahawal Victoria Hospital, Bahawalpur.

\section{Methodology:-}

Study design:

Cross sectional descriptive study.

\section{Setting:}

The setting of the study was blood bank of Bahawal Victoria Hospital, Bahawalpur.

\section{Study Duration:}

Study was started in May 2018 and completed in June 2018.

\section{Sample size:}

A sample of 100 people was taken.

\section{Sampling technique:}

Non probability convenient sampling.

\section{Ethical issues:}

Informed consent was taken from all participants. Expenses were born by researchers.

\section{Inclusion Criteria:}

All the willing subjects were included in our study.

\section{Exclusion Criteria:}

All the subjects who were not willing were excluded from our study.

\section{Data collection protocol:}

The information was collected through a preformed questionnaire. The information regarding results of the screening tests of $\mathrm{HBV}, \mathrm{HCV}, \mathrm{HIV}$ and syphilis of blood donors performed at the time of donation was collected from the previous record.

\section{Data analysis:}

Data was analyzed manually. All results were presented in the form of tables and graphs. 


\section{Results:-}

In this study we conducted 100 subjects were included out of which $87 \%(\mathrm{~N}=87)$ were males and $13 \%(\mathrm{~N}=13)$ were females. (Figure.1) $17 \%$ of the subjects were infective, in which $94.12 \%(\mathrm{~N}=16)$ were males and 5.88\% $(\mathrm{N}=1)$ were females.(Figure 2) $83 \%$ of subjects were non-infective, in which $85.54 \%(\mathrm{~N}=71)$ were males and $14.46 \%$ $(\mathrm{N}=12)$ were females. (Figure 2)

$23 \%$ of respondents were illiterate, in which $78.26 \%(\mathrm{~N}=18)$ were males and $21.74 \%(\mathrm{~N}=5)$ were females. Among these $17.39 \%(\mathrm{~N}=4)$ were infective $(50 \%(\mathrm{~N}=2) \mathrm{HBV}+\mathrm{ive}, 50 \%(\mathrm{~N}=2) \mathrm{HCV}+\mathrm{ive})$ and $82.61 \%(\mathrm{~N}=19)$ were noninfective.(Figure 5) Among the respondents who completed their primary education were $18 \%$ in which $94.44 \%$ $(\mathrm{N}=16)$ were males and $5.56 \%(\mathrm{~N}=2)$ were females. Among these $22.22 \%(\mathrm{~N}=4)$ were infective $(75 \%(\mathrm{~N}=3) \mathrm{HCV}$ +ive, 25\% (N=1) T.P +ive) and $77.78 \%(\mathrm{~N}=14)$ were non-infective.(Figure 5). Respondents whose level of education was upto matriculation were $33 \%$ in which $93.94 \%(\mathrm{~N}=31)$ were males and $6.06 \%(\mathrm{~N}=2)$ were females. Among these $24.25 \%(\mathrm{~N}=8)$ were infective $(37.5 \%(\mathrm{~N}=3) \mathrm{HCV}+\mathrm{ive}, 25 \%(\mathrm{~N}=2) \mathrm{HBV}+\mathrm{ive}, 37.5 \%(\mathrm{~N}=3) \mathrm{T} . \mathrm{P}+\mathrm{ive})$ and $75.75(\mathrm{~N}=25) \%$ were non-infective. (Figure.5) Among the respondents who complete their education upto graduation were $26 \%$, out of which $80.77 \%(\mathrm{~N}=21)$ were males and $19.23 \%(\mathrm{~N}=5)$ were females. Among these $3.84 \%(\mathrm{~N}=1)$ were $\mathrm{HBV}$ +ive and $96.16 \%(\mathrm{~N}=25)$ were non-infective. (Figure.5).

Among the candidates $9 \%$ had previous $\mathrm{H} / \mathrm{o}$ jaundice in which $77.77 \%(\mathrm{~N}=7)$ were males and $22.23 \%(\mathrm{~N}=2)$ were females. Out of these $44.45 \%(\mathrm{~N}=4)$ were infective $(50 \%(\mathrm{~N}=2) \mathrm{HBV}+\mathrm{ive}, 50 \%(\mathrm{~N}=2) \mathrm{HCV}+\mathrm{ive})$ and $55.55 \%$ $(\mathrm{N}=5)$ were non-infective.(Table.2). Among the subjects who were interviewed, $51 \%$ were having $\mathrm{H} / \mathrm{o}$ blood transfusion, in which 94.12\% ( $\mathrm{N}=48)$ were males and 5.88\% $(\mathrm{N}=3)$ were females. Among these $15.68 \%(\mathrm{~N}=8)$ were infective $(50 \%(\mathrm{~N}=4) \mathrm{HCV}+\mathrm{ive}, 12.5 \%(\mathrm{~N}=1) \mathrm{HBV}+\mathrm{ive}, 37.5 \%(\mathrm{~N}=3) \mathrm{T} . \mathrm{P}+\mathrm{ive})$ and $84.32 \%(\mathrm{~N}=43)$ were non-infective.

Among the respondents $25 \%$ had $\mathrm{H} / \mathrm{o}$ needle prick, in which $88 \%(\mathrm{~N}=22)$ were males and $12 \%(\mathrm{~N}=3)$ were females. Among these $12 \%(\mathrm{~N}=3)$ were $\mathrm{HCV}$ +ive and $88 \%(\mathrm{~N}=22)$ were non-infective.(Figure. 7$)$. $18 \%$ of the respondents were having $\mathrm{H} / \mathrm{o}$ using common pins in teeth, in which $94.44 \%(\mathrm{~N}=17)$ were males and $5.56 \%(\mathrm{~N}=1)$. were females.Among these $27.77 \%(\mathrm{~N}=5)$ were infective $(60 \%(\mathrm{~N}=3) \mathrm{HCV}+\mathrm{ive}, 40 \%(\mathrm{~N}=2) \mathrm{HBV}+\mathrm{ive})$ and $72.23 \%$ $(\mathrm{N}=13)$ were non-infective. $13 \%$ of the respondents had $\mathrm{H} / \mathrm{o}$ ear \& nose piercing, out of these $7.69 \%(\mathrm{~N}=1)$ were males and $92.31 \%(\mathrm{~N}=12)$ were females. Among these $7.69 \%(\mathrm{~N}=1)$ were infected with $\mathrm{HCV} \& 92.31 \%(\mathrm{~N}=12)$ were non-infective.

$24 \%$ of the individuals who were interwiewed have $\mathrm{H} / \mathrm{o}$ sharing of scissors, out of these $87.5 \%(\mathrm{~N}=21)$ were males and $12.5 \%(\mathrm{~N}=3)$ were females. Among these $16.66 \%(\mathrm{~N}=4)$ were infective $(75 \%(\mathrm{~N}=3) \mathrm{HCV}+\mathrm{ive}, 25 \%(\mathrm{~N}=1)$ T.P +ive) \& $83.34 \%(\mathrm{~N}=20)$ were non-infective.(Figure.9). Among the candidates who were interviewed $63 \%$ were having $\mathrm{H} / \mathrm{o}$ sharing of nail-cutters, in which $85.72 \%(\mathrm{~N}=54)$ were males and $14.28 \%(\mathrm{~N}=9)$ were females. Out of these $11.11 \%(\mathrm{~N}=7)$ were infective $(57.14 \%(\mathrm{~N}=4) \mathrm{HCV}+\mathrm{ive}, 28.58 \%(\mathrm{~N}=2) \mathrm{HBV}+\mathrm{ive}, 14.28 \%(\mathrm{~N}=1) \mathrm{T} . \mathrm{P}+\mathrm{ive})$ and $88.89 \%(\mathrm{~N}=54)$ were non-infective.Among the participants $8 \%$ had $\mathrm{H} / \mathrm{o}$ tooth-brush sharing, in which $100 \%(\mathrm{~N}=8)$ were males \& no females. Out of these $50 \%(\mathrm{~N}=4)$ were infective $(50 \%(\mathrm{~N}=2) \mathrm{HCV}+\mathrm{ive}, 25 \%(\mathrm{~N}=1) \mathrm{HBV}+\mathrm{ive}$, $25 \%(\mathrm{~N}=1)$ T.P $+\mathrm{ive})$ and $50 \%(\mathrm{~N}=4)$ were non-infective. $18 \%$ of the respondents were having H/o sharing of razor, all were males.(Figure. 9). Among these $16.67 \%(\mathrm{~N}=3)$ were infected with HCV \& 83.33\% (N=15) were noninfective.56\% among the respondents were having $\mathrm{H} / \mathrm{o}$ shaving from barber, all were males.(Figure 9). Out of these 19.64\% ( $\mathrm{N}=11)$ were infective $(45.45 \%(\mathrm{~N}=5) \mathrm{HCV}+\mathrm{ive}, 36.36 \%(\mathrm{~N}=4) \mathrm{HBV}+\mathrm{ive}, 18.19 \%(\mathrm{~N}=2) \mathrm{T} . \mathrm{P}+\mathrm{ive}) \&$ $80.36 \%(\mathrm{~N}=45)$ were non-infective.

$8 \%$ of candidates who were interviewed had H/o tattooing, all were males. Among these $50 \%(\mathrm{~N}=4)$ were infective $(50 \%(\mathrm{~N}=2) \mathrm{HCV}+\mathrm{ive}, 25 \%(\mathrm{~N}=1) \mathrm{HBV}+\mathrm{ive}, 25 \%(\mathrm{~N}=1) \mathrm{T} . \mathrm{P}+\mathrm{ive})$ (Figure 16) \& $50 \%(\mathrm{~N}=4)$ were noninfective. $31 \%$ among candidates were intra-venous drug users, Among these $80.64 \%(\mathrm{~N}=25)$ were males \& $19.36 \%$ $(\mathrm{N}=6)$ were females. Out of these $19.36 \%(\mathrm{~N}=6)$ were infective $(50 \%(\mathrm{~N}=3) \mathrm{HCV}+\mathrm{ive}, 16.67 \%(\mathrm{~N}=1) \mathrm{HBV}+\mathrm{ive}$, $33.33 \%(\mathrm{~N}=2)$ T.P +ive) \& 80.64\% $(\mathrm{N}=25)$ were non-infective.( Figure $6 \& 7)$.

$12 \%$ among the respondents were having $\mathrm{H} / \mathrm{o}$ previous surgical intervention, among these $58.33 \%(\mathrm{~N}=7)$ were males and $41.67 \%(\mathrm{~N}=5)$ were females. All were non-infective.2\% among the respondents had H/o previous gyne/obst. Intervention. All of them were females. All were non- infective.12\% among the respondents were having previous $\mathrm{H} / \mathrm{o}$ tooth extraction \& other dental procedures, in which $91.67 \%$ $(\mathrm{N}=11)$ were males and $8.33 \%(\mathrm{~N}=1)$ were females. Out of these $8.33 \%(\mathrm{~N}=1)$ were $\mathrm{HCV}+\mathrm{ive}$ and $91.67 \%$ $(\mathrm{N}=11)$ were non-infective. 
99\% of respondents were following Islam \& have no illegitimate sexual relationship.Among these $87.87 \%$ (N=87) were males and $12.13 \%(\mathrm{~N}=12)$ were females.Out of these $11.11 \%(\mathrm{~N}=11)$ were infective $(36.36 \%(\mathrm{~N}=4) \mathrm{HCV}$ +ive, $36.36 \%(\mathrm{~N}=4) \mathrm{HBV}+\mathrm{ive}, 27.28 \%(\mathrm{~N}=3) \mathrm{T} . \mathrm{P}+\mathrm{ive}) \& 88.89 \%(\mathrm{~N}=88)$ were non-infective.

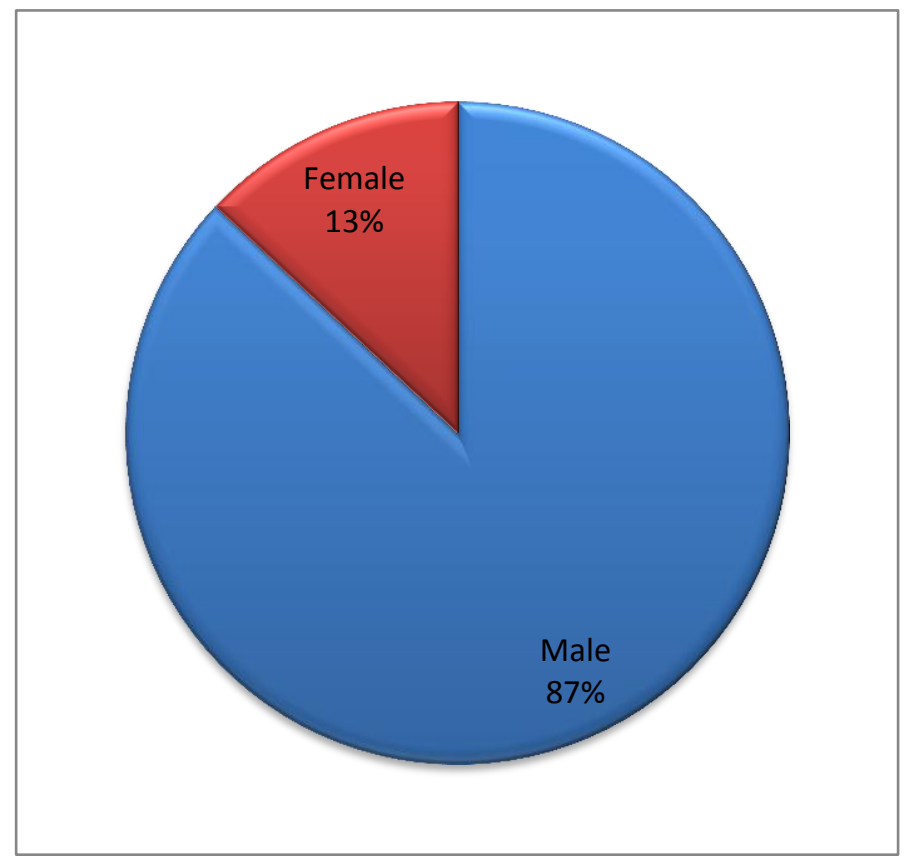

Fig 1:-Gender Distribution Among Donors.

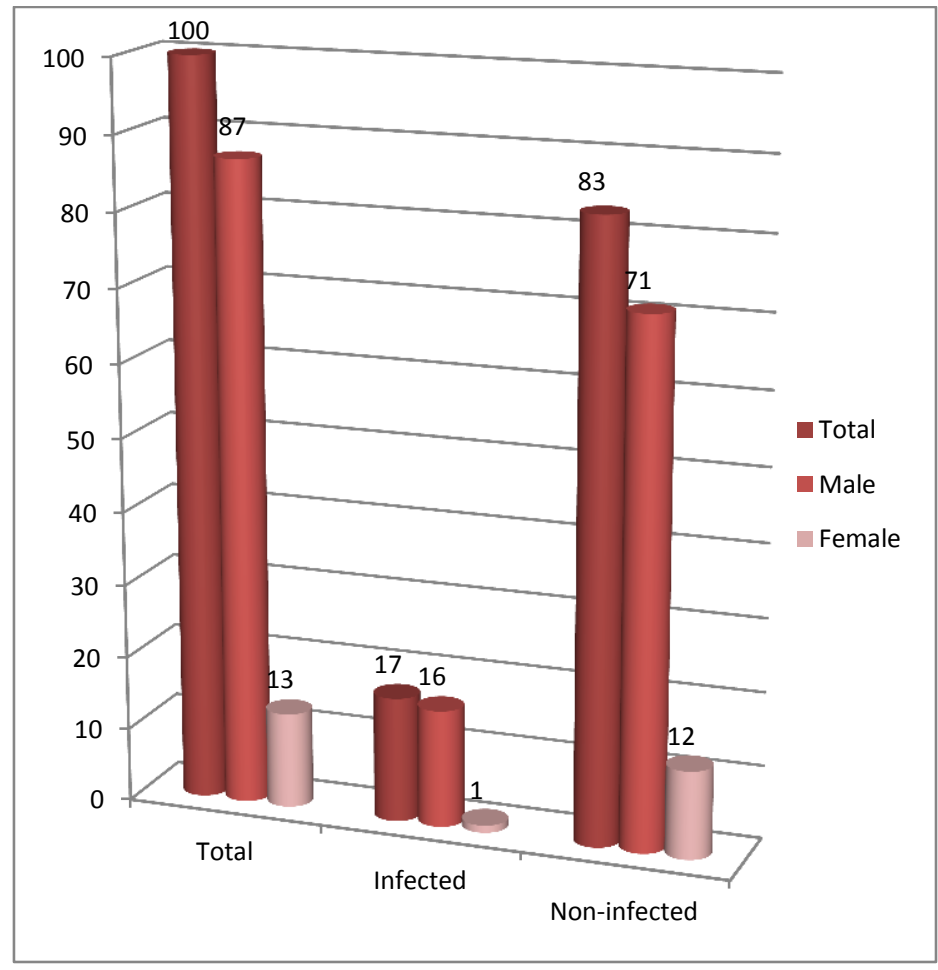

Fig 2:-Frequency Of Infection Among Male And Female Donor 


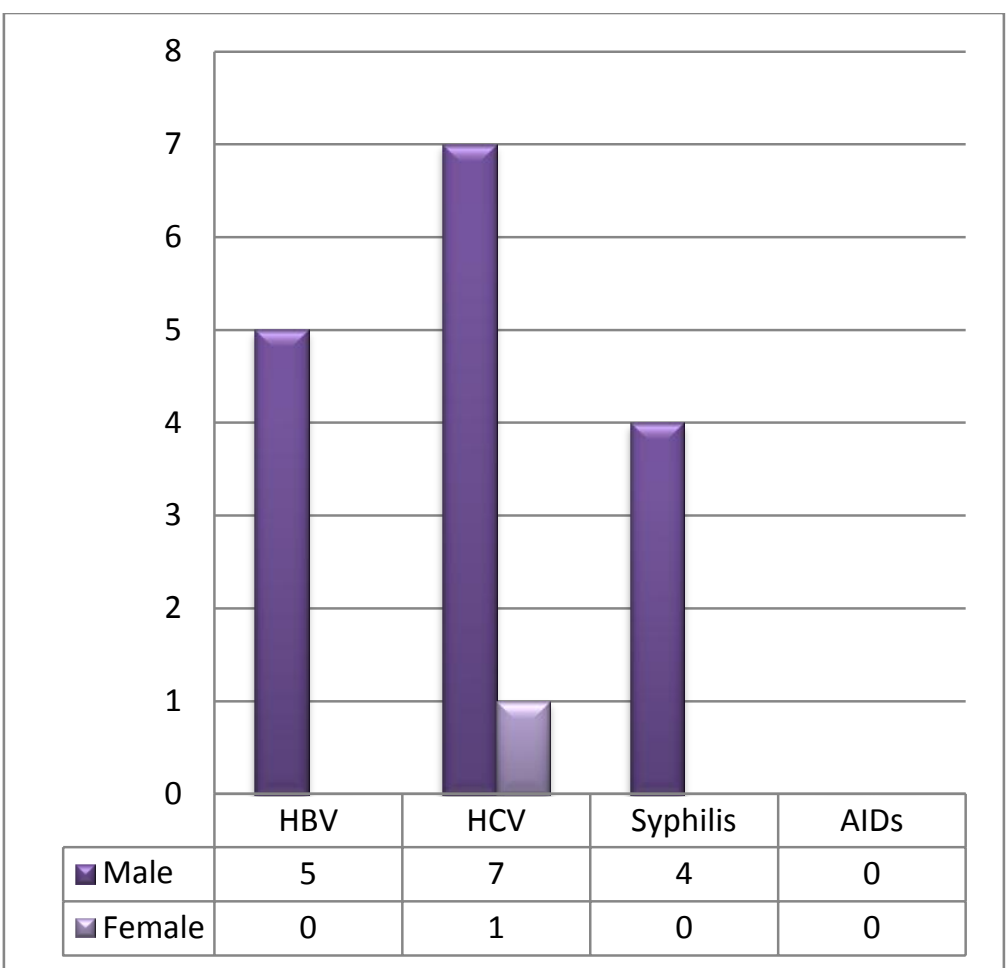

Fig 3:-Frequency of infections in males and female donors.

Table 1:-Educational Status of subjects under study.

\begin{tabular}{|l|l|l|}
\hline Educational Status & Male & Female \\
\hline Illiterate & 18 & 5 \\
\hline Primary & 17 & 1 \\
\hline Matriculation & 31 & 2 \\
\hline Graduation & 21 & 5 \\
\hline Total & 87 & 13 \\
\hline
\end{tabular}

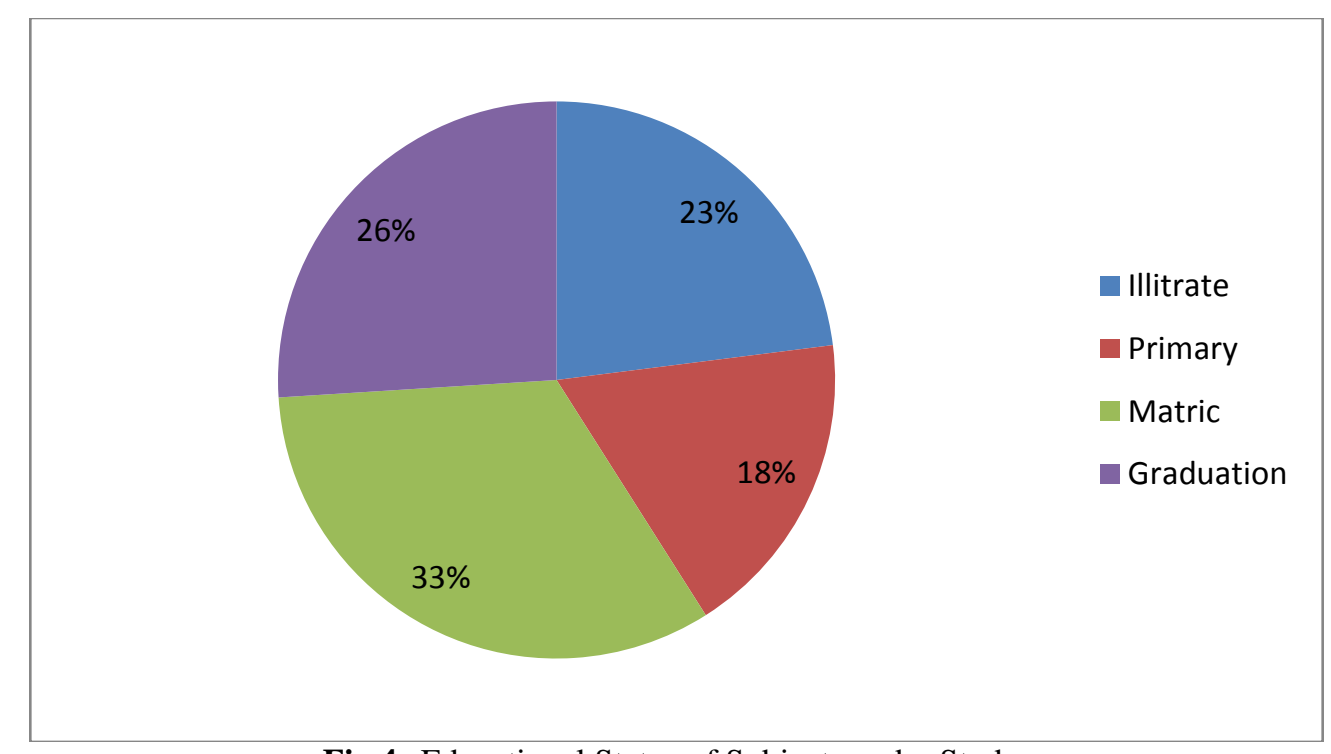

Fig 4:-Educational Status of Subjects under Study. 


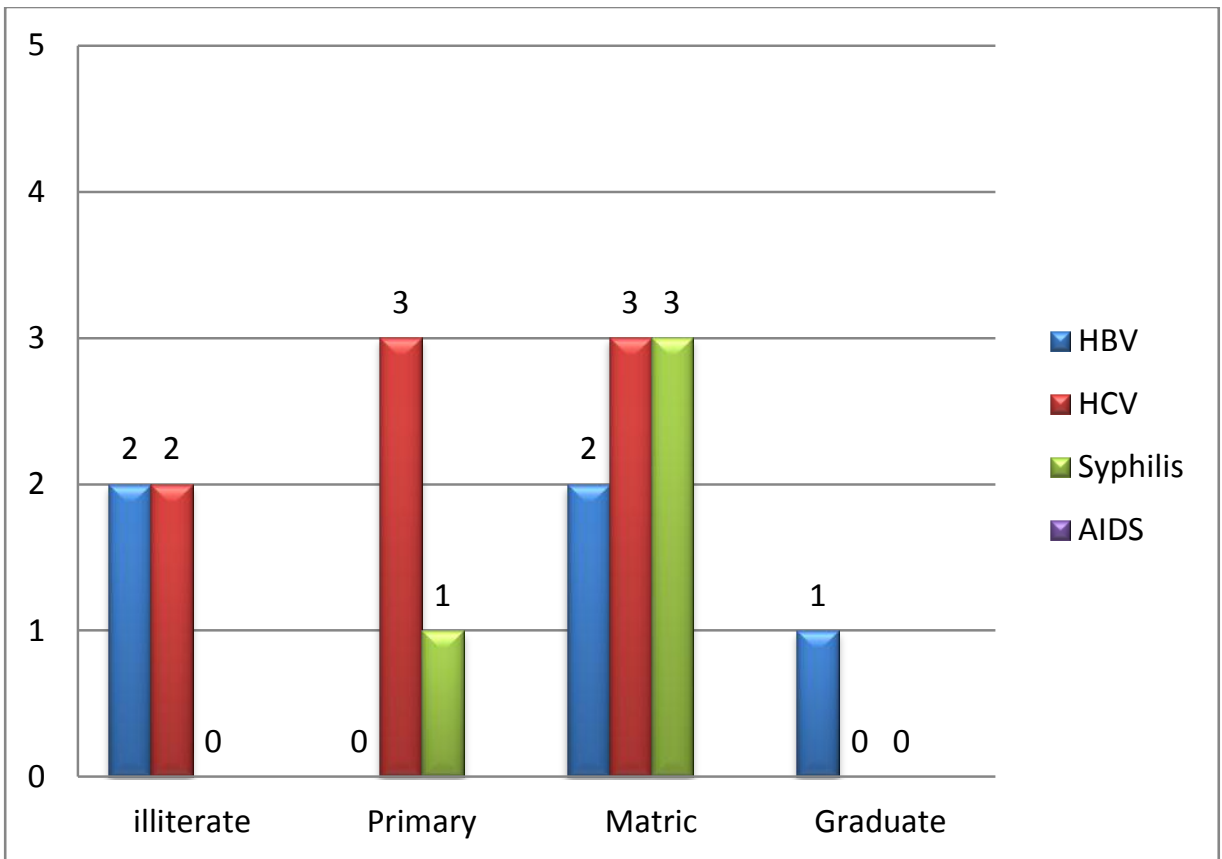

Fig 5:-Frequency of Infections In Educational classes.

Table 2:-Frequency of HBV \& HCV Infections Among Respondents with H/O Jaundice.

\begin{tabular}{|c|c|c|c|c|c|}
\hline \multirow{2}{*}{$\begin{array}{l}\mathrm{H} / \mathrm{O} \\
\text { JAUNDICE }\end{array}$} & \multicolumn{4}{|c|}{ Infection } & \multirow[t]{2}{*}{ TOTAL } \\
\hline & HBV & $\mathrm{HCV}$ & Syphilis & AIDS & \\
\hline YES & 2 & 2 & 0 & 0 & 4 \\
\hline $\mathrm{NO}$ & 3 & 6 & 4 & 0 & 13 \\
\hline TOTAL & 5 & 8 & 4 & 0 & \\
\hline
\end{tabular}

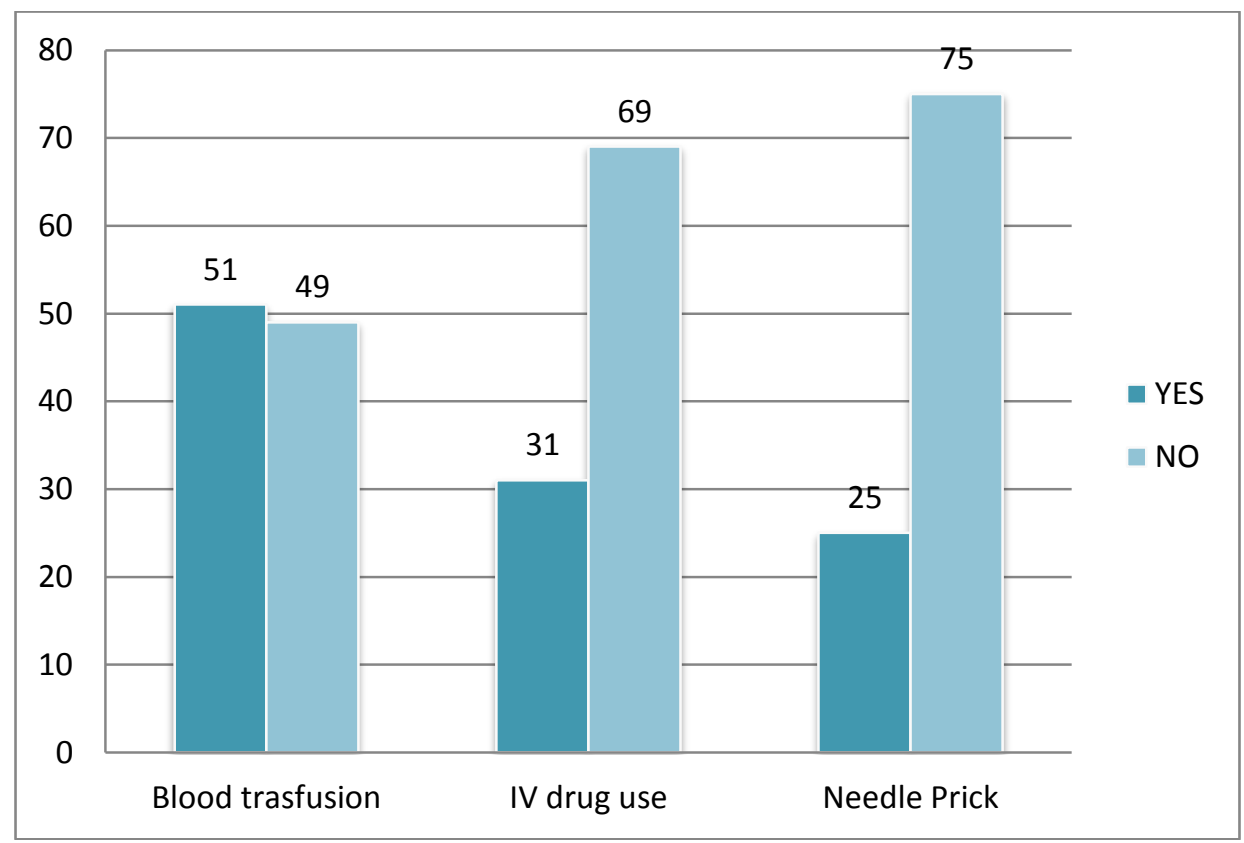

Fig 6:-Frequency of H/O Blood transfusion, I/V drug use ,needle pricks among donors. 


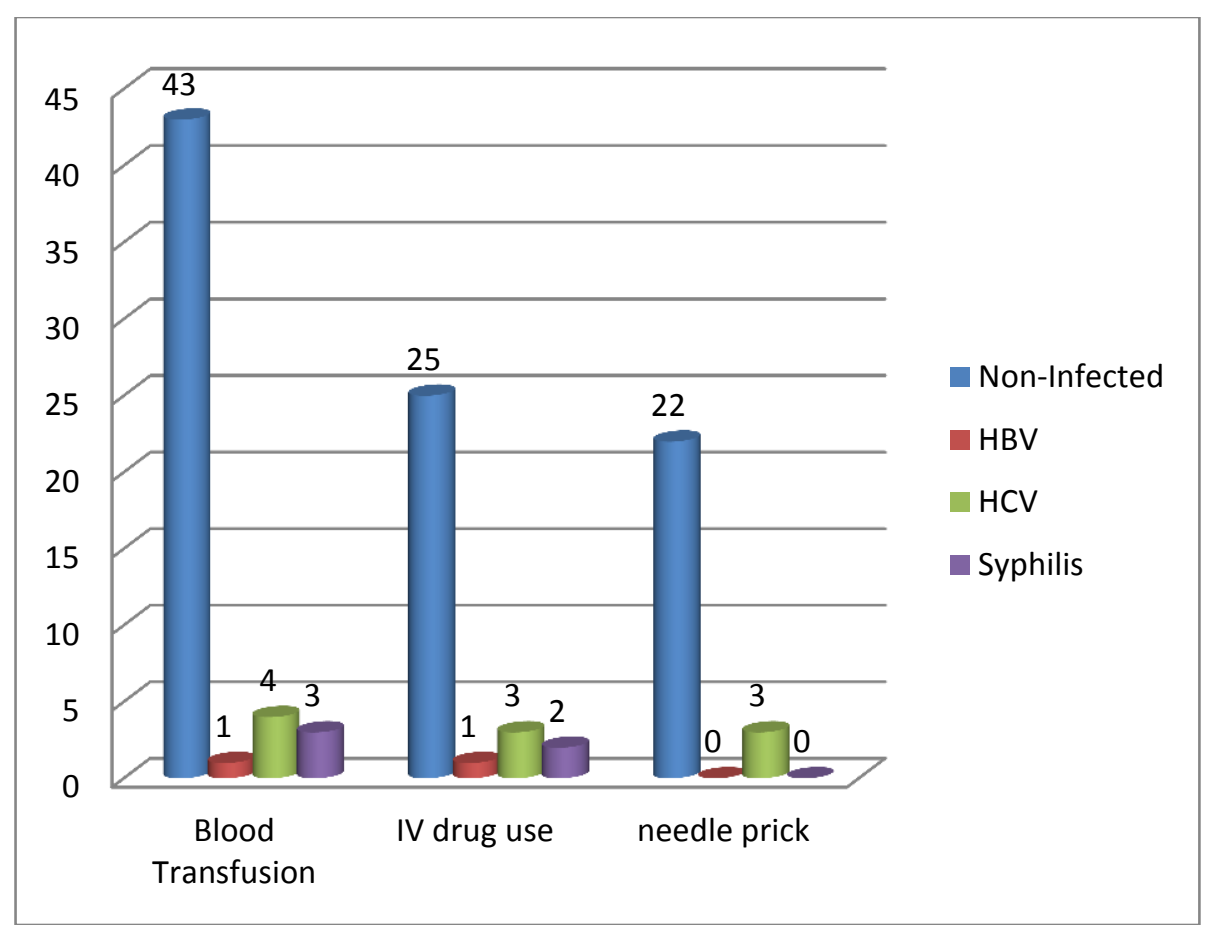

Fig 7:-Frequency of infections in respondents with H/O Blood transfusion, I/V drug usurers \& needle pricks.

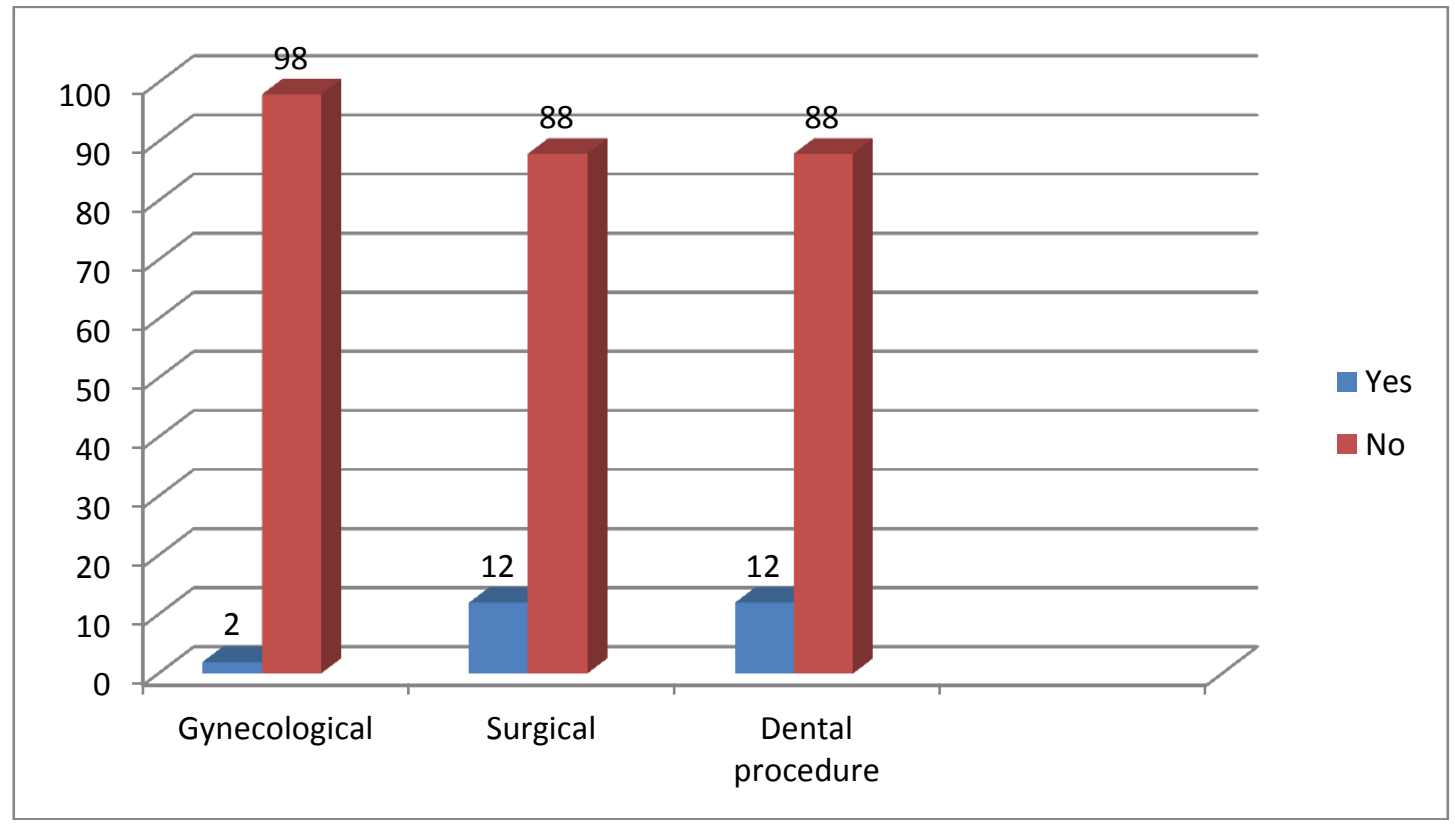

Fig 8:-H/O Gynecological, Surgical \& Dental procedures in Subjects. 


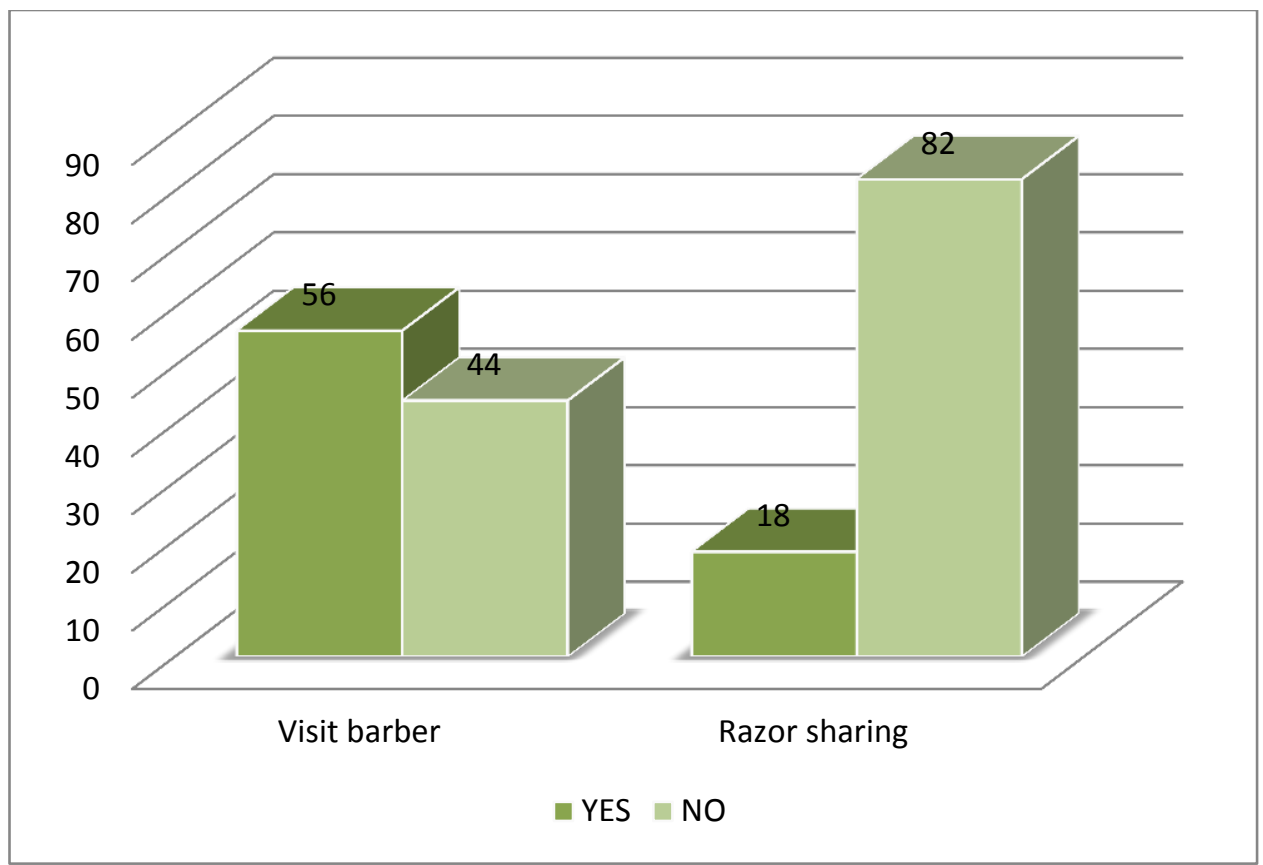

Fig 9:-Frequency of $\mathrm{H} / \mathrm{O}$ visiting barber \& sharing razors.

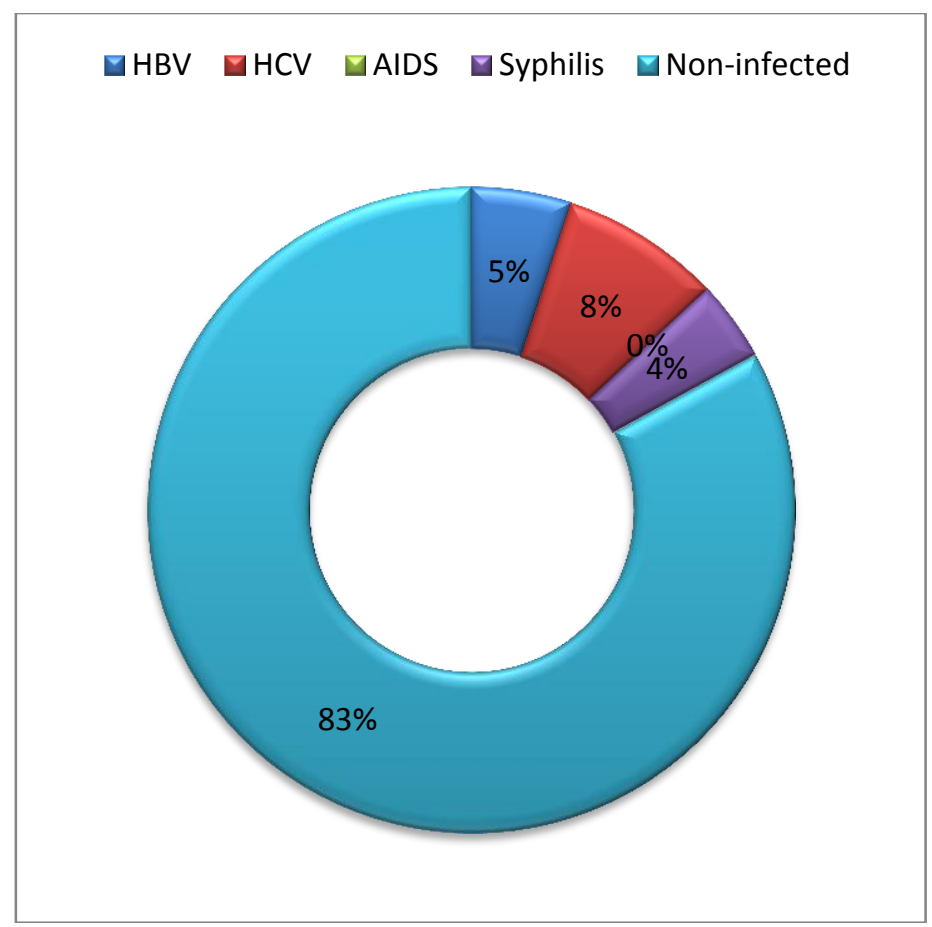

Fig 10:-Frequency of Infections in barber visitor 




Fig 11:-Frequency of H/O Scissor Sharing \& Nail- cutter Sharing in Subjects.

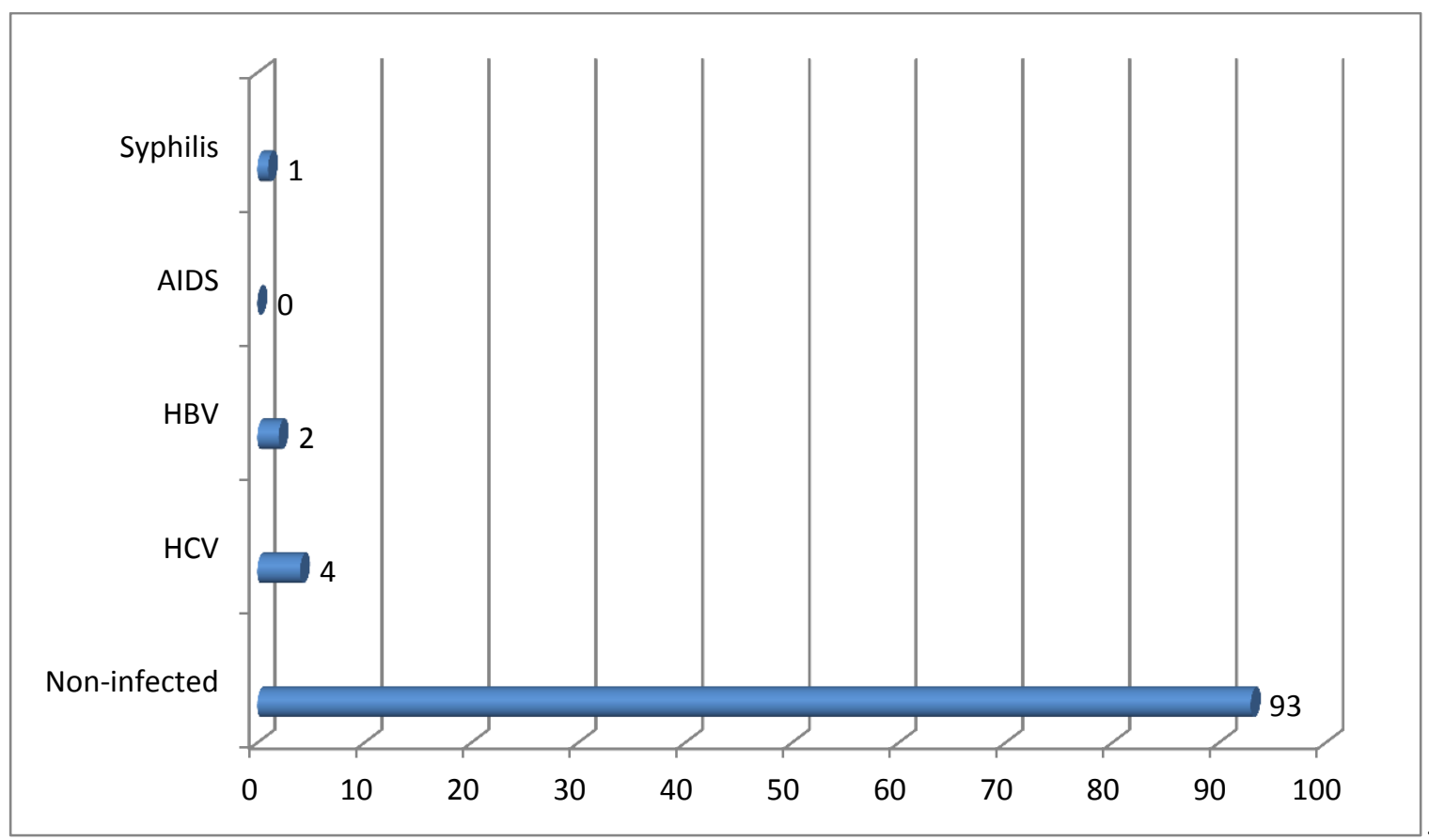

Fig 12:-Frequency of Infections in Nail-cutter Sharers. 


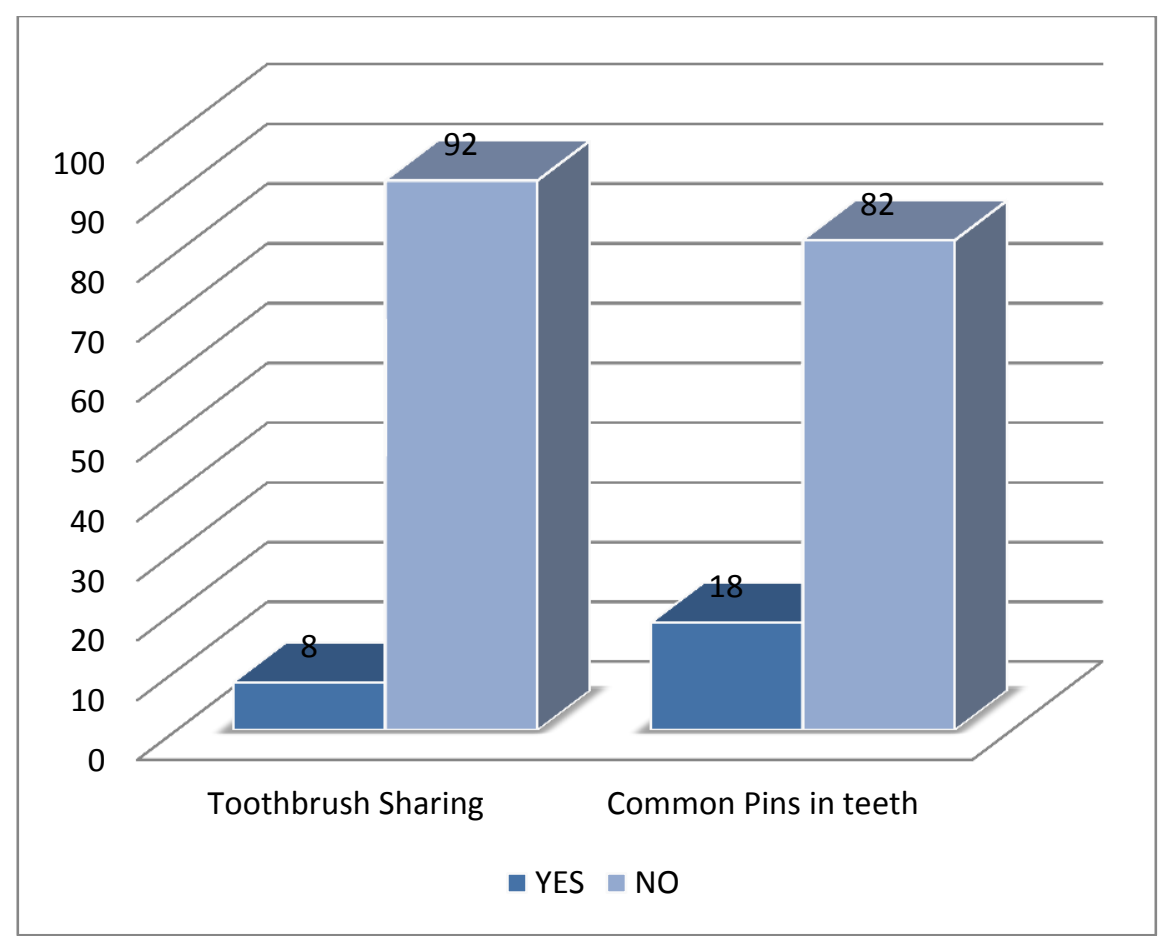

Fig 13:-H/O Tooth-brush sharing \& Common pin usage in teeth.

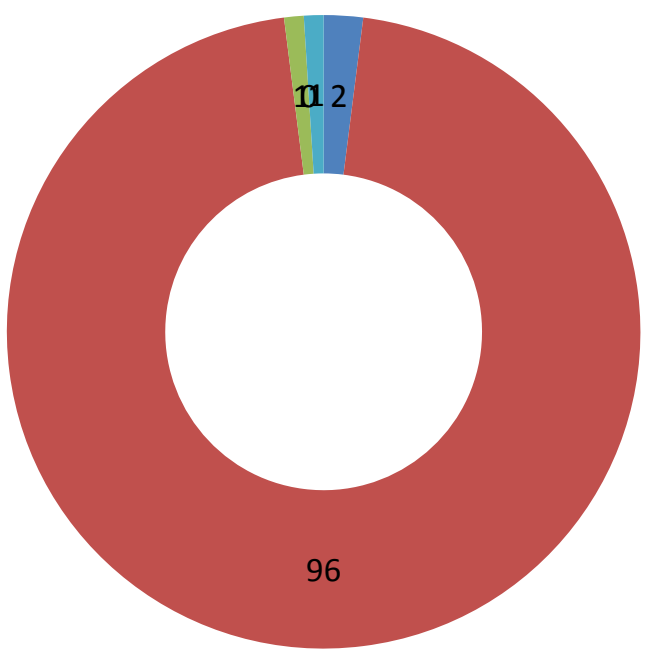

- HCV

Non-infective

HBV

AIDS

Syphilis

Fig 14:-Frequency of infections in subjects having H/O Tooth-brush sharing. 


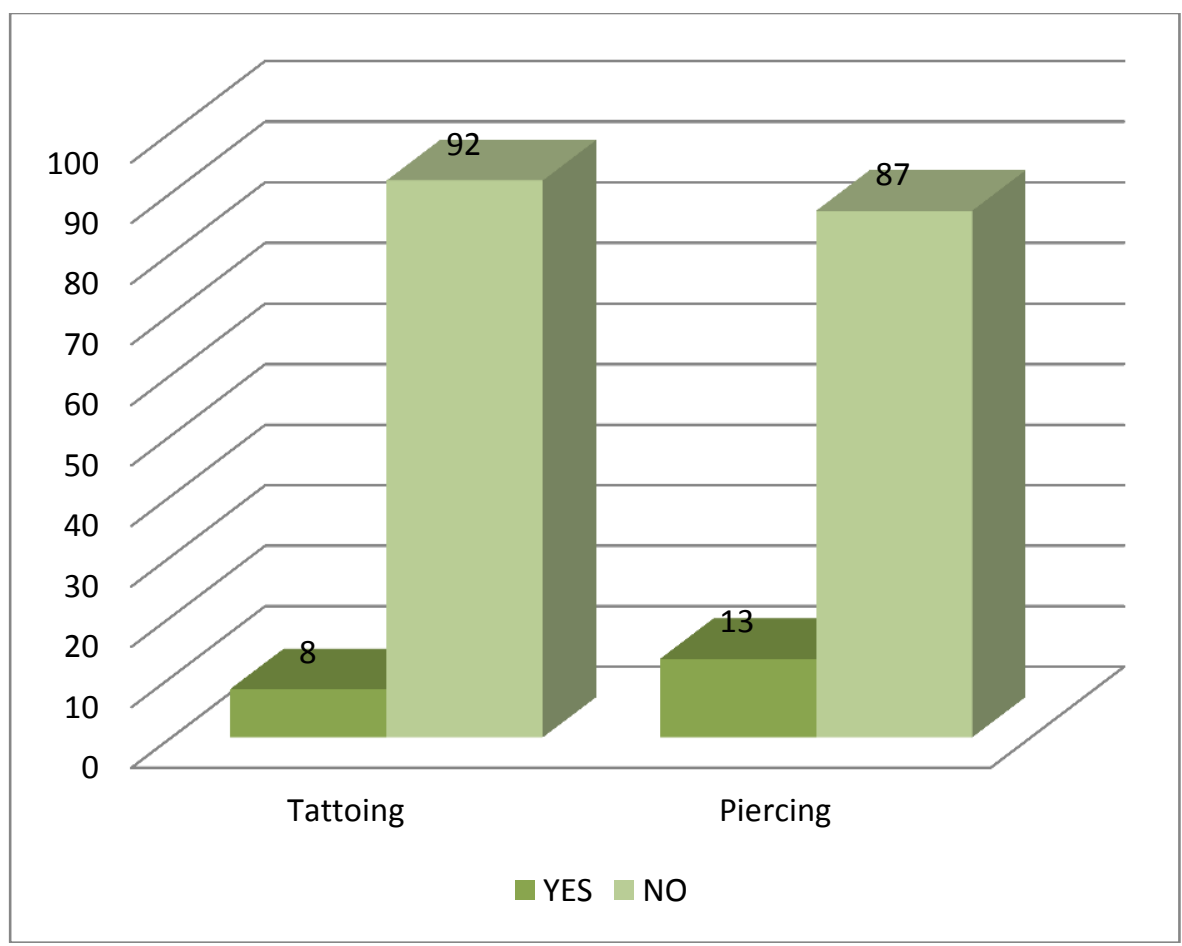

Fig 15:-Frequency of H/O Piercing \& tattooing among blood donors.



\section{Conclusion:-}

Fig 16:-Frequency of infections in Subjects having H/O Tattooing.

Sharing of scissors, shaving from barber and I/V drug using practices/reuse of syringes were surprisingly frequent among people, which had top-listed the risk factors for hepatitis and AIDS. The most frequent infection among blood donors was hepatitis C 8\%, followed by hepatitis B 5\% and syphilis 4\%. The results seek an urgency to create awareness among people regarding these risk factors. 


\section{Recommendations:-}

1. Awareness should be created among masses to avoid nail-cutter and scissor sharing.

2. Public should be educated (through electronic \& print media) regarding shaving from barber they should use sterilized razor/blade and avoid cuts.

3. Awareness should be created among people, that they do not have any illegitimate sexual relationship, as this is a risk factor for transmission of Hepatitis and AIDS.

4. Seminars should be conducted to create awareness among people about prevention and consequences of hepatitis and AIDS.

5. Proper labeling of the infected samples should be done by nursing staff of hospital immediately after taking the sample right at the bed-side.

6. All the persons (nurses, lab technicians and attendants etc.) who are involved In handling of infected samples should be careful to avoid needle pricks.

7. Proper screening should be done before undergoing blood-transfusion to reduce the risk of infection.

8. All the paramedics and operation- theater staff should be trained to sterilize the surgical instruments properly. All the surgical procedures should be done under aseptic conditions.

9. It is mandatory to use separate set of surgical instruments should for infected patients.

10. Public should be pursued to immunize themselves against hepatitis B to avoid deadly complications of this diseases.

11. All the infected materials (syringes, blood bags and screening kits etc.) should be handled and disposed- off carefully.

12. Tattooing and I/V drug using practices should be discouraged.

13. Legislative measures should be taken against unnecessary transfusion of blood by general practitioners in periphery, and blood transfusion should only be allowed at specialized centers after proper screening.

\section{References:-}

1. WHO Guidelines of Blood Transfusion Safety Appia, CH-1211 Geneva 27, Switzerland.

2. Standards for Blood Banks and transfusion Services ed 18. American Association of Blood Banks, Bethesda, MD, 1997; 41: 120-23.

3. Asif N, Kokhar N, Ilahi F. Seroprevalence of HBV, HCV and HIV infection among voluntary non Remunerated and replacement donors in Northern Pakistan. Pak J Med Sci 2004; 20 (1): 24-8.

4. Rahman M, Akhtar G, Qadeer M, Shams T, Usmani A, Lodhi Y. Safe blood begins with safe donors. Pak J Med Sci 2003; 19 (3): 161-8.

5. Arora D, Arora B, Khetarpal A. Seroprevalence of HIV, HBV, HCV and syphilis in blood donors in Southern Haryana. Indian J Pathol Microbiol 2010;53:308-9

6. Hutin Y, Kitler ME, Dore GJ, Perz JF, Armstrong,GL, Dusheiko G et al. Global burden of disease (GBD) for hepatitis C. J Clin Pharmacol 2004;44:20-29

7. Pakistan Medical Research Council. Prevalence of Hepatitis B and C in Pakistan. 2008. Pakistan Medical Research Council, Ministry of Health, Government of Pakistan

8. Bibi I, Devrajani BR, Shah SZA, Soomro MH, Jatoi MA. Frequency of syphilis in female sex workers at red light area of Hyderabad, Pakistan. J Pak Med Assoc. Vol. 60 (5) May 2010; 353-56

9. Waheed U. HIV/AIDS: Evaluation of Kits and Formulation of a Testing Strategy for Pakistan, 2012. LAP Lambert Academic Publishing. ISBN 978-3847314462

10. Tropical Journal of Pharmaceutical Research February 2012; 11 (1): 132-136

11. Et al. Ann. Pak. Inst. Med. Sci. 2012; 8(4): 236-239

12. UN Office for the Coordination of Humanitarian Affairs PAKISTAN: Unsafe blood transfusions pose HIV, hepatitis risk. Humanitarian news and analysis 05 March 2009.

13. Moukoko C., Sack F., Same E. HIV, HBV, HCV and T. Pallidum infections among blood donors and Transfusion related complications among recepients at the Laquintinie hospital in Douala, Cameroon BMC Hematology 2014, 14: 5-14.

14. Singh S., Singh U., Kol P. Transfusion transmitted infections among the blood donors in Central India. Indian Journel of Research, PARIPEX 2015, 4(4): 4-6.

15. Haritwal A., Puja, Mishra J., Ojha J. Prevalence of transfusion transmitted diseases among the Bloob donors at a tertiary care teaching hospital in India. Acta velit 2015, 1 (2): 25-30 
16. Ijeoma H., Nwabuko C., Chuku A., Ajuogu E. and Dorathy O. Prevalence of Human immunodeficiency virus, Hepatitis B virus, Hepatitis C virus and syphilis in blood donors in a tertiary health facility in southeast Nigeria. Hematology and Leukemia 2012, 2: 191-221.

17. Tessema B., Yismaw G., Kassu A., Amsalu A. and Mulu A. Seroprevalence of HIV, HBV, HCV and Syphilis infection among blood odnors at Gondar University Teaching Hospital, Northwest Ethopia. BMC infectious diseases 2010, $10: 111-116$.

18. Kolen F, Oztop Y, Engin A. Investigation of Hepatitis virus DNA in positive blood donors. Sci. Res. Essays $6(13) ; 2720-23$.

19. Hollinger FB. Hepatitis B virus infection and transfusion medicine: Science and occult. Transfusion:48 :100126

20. Gulia SP, Panda S, Sitaraman E. seroprevelance of hepatitis B virus infection among blood donors in local population. Internet. J. Pathol.12(1).

21. Al-Robasi AA, AL- Harbil. Prevalence of markers for Human immune deficiency virus, hepatitis B and syphilis among blood donors in yemen. YemeniMed J 1996 ; 2 :58-60.

22. Hammet TM :HIV/AIDS and other infectious diseases among correctional inmates: transmission burden, and an appropriate response. AM J public health 2006,96: 794-78

23. Adijei, A.A, KHudzi, W, Armah, H; prevalence of antibodies to syphilis among blood donors. JPN Infect Dis, vol 56,N 4,PP.165-7

24. Mbanya DN, Takam D, serological finding amongst first time blood donors in Cameron. Transfus Med. 2003; 13:267-7. 